\title{
Indoor air quality in rural Southwestern Uganda: particulate matter, heavy metals and carbon monoxide in kitchens using charcoal fuel in Mbarara Municipality
}

\author{
Nicholas Nakora ${ }^{1}$. Denis Byamugisha ${ }^{1} \cdot$ Grace Birungi ${ }^{1}$ []
}

Received: 26 August 2020 / Accepted: 29 October 2020 / Published online: 20 November 2020

(c) Springer Nature Switzerland AG 2020

\begin{abstract}
The use of biomass energy over open fires in sub-Saharan Africa is rampant yet it is associated with air pollution. Information on the contribution of common biomass like charcoal to indoor air pollution in Uganda is scarce; therefore, kitchen-indoor air in charcoal fueled kitchens was characterized for fine particulate matter $\left(\mathrm{PM}_{2.5}\right)$, heavy metals and carbon monoxide content in Mbarara Municipality Western Uganda. $\mathrm{PM}_{2.5}$ was measured using University of California Berkeley Particle and Temperature Sensor (UCB-PATS), heavy metals were determined using Inductively Coupled Plasma Optical Emission Spectrometry (ICP-OES) and carbon monoxide was measured using a portable, battery-operated, datalogging Drager Pac 7000. In the kitchens assessed, the mean 24-h concentration for $P M_{2.5}$ was $0.449 \mathrm{mg} / \mathrm{m}^{3}$ in the wet season and $0.526 \mathrm{mg} / \mathrm{m}^{3}$ in the dry season; $\mathrm{CO}$ was $41.52 \mathrm{ppm}$, and all concentrations were higher than the World Health Organization 24-h Air Quality Guideline for $\mathrm{PM}_{2.5}$ of $0.024 \mathrm{mg} / \mathrm{m}^{3}$ and $\mathrm{CO}$ of $6.340 \mathrm{ppm}$. Heavy metals in particulate matter were in concentration ranges of $1.012-9.820 \mu \mathrm{g} / \mathrm{m}^{3} \mathrm{Fe}, 0.012-0.092 \mu \mathrm{g} / \mathrm{m}^{3} \mathrm{Cr}, 0.060-10.750 \mu \mathrm{g} / \mathrm{m}^{3} \mathrm{Zn}, 0.048-0.300 \mu \mathrm{g} /$ $\mathrm{m}^{3} \mathrm{Cu}, 0.004-0.052 \mu \mathrm{g} / \mathrm{m}^{3} \mathrm{~Pb}$ and $\mathrm{ND}-0.004 \mu \mathrm{g} / \mathrm{m}^{3} \mathrm{Cd}$. All mean metal concentrations were lower than recommended exposure levels by EPA although chronic exposure is a risk to health. Kitchen ventilation and size were found to significantly influence indoor pollutant levels; charcoal fuel significantly contributed to indoor air pollution and is therefore a risk factor to human health.
\end{abstract}

Keywords Charcoal $\cdot$ Carbon monoxide $\cdot$ Indoor air pollution $\cdot$ Particulate matter $\cdot$ Heavy metals

\section{Article Highlights}

- Charcoal fuel generates particulate matter, carbon monoxide and heavy metals which pollutes indoor air pollution especially in kitchens

- While the concentration of heavy metals was lower than recommended EPA concentrations, it is important to note that chronic exposure is a health risk

- In order to reduce this pollution, kitchens should be well ventilated; we recommend that people in rural areas should endeavor to increase the kitchen size and improve ventilation

\section{Introduction}

Air pollution although more pronounced in low- or middle-income countries in Asia and Africa is a global challenge. Poor air quality indoors is estimated to be responsible for $2.7 \%$ and $3.7 \%$ of the global and developing countries disease burden respectively [1]; it is associated with respiratory diseases such as lung cancer and pneumonia [2] which are detrimental to health. Indoor air pollution due to inefficient and poorly ventilated stoves burning biomass fuels such as wood, crop waste and dung, or coal is responsible for the deaths of an estimated

Grace Birungi, gbirungi@must.ac.ug; Nicholas Nakora, nnakora@std.must.ac.ug; Denis Byamugisha, dbmugisha@must.ac.ug |

${ }^{1}$ Department of Chemistry, Mbarara University of Science and Technology, Mbarara-Kabale Road, P.O Box 1410, Mbarara, Uganda. 
1.6 million people annually; more than half of which occur among children under 5 years of age [3].

Biomass in it various forms provides over $90 \%$ of primary energy in most developing nations [4] where the majority of people depend on charcoal, fire wood or agricultural wastes for their energy needs [5]; for example, $93 \%$ of the energy consumption in Uganda is wood fuel (firewood and charcoal) and agricultural wastes $[6,7]$ and in urban areas, $65.7 \%$ of the households use charcoal while $33.4 \%$ use firewood for cooking [8] yet biomass is a source of air pollutants [3, 8-10]. Knowledge about specific biomass contribution to air pollution in Uganda is limited, thus emissions from kitchens using charcoal as the main source of energy in Mbarara Municipality Western Uganda were investigated to determine the contribution of charcoal usage to indoor air pollution.

Biomass contributes to indoor air pollutants such as particulate matter and carbon monoxide resulting from its combustion [11]. Particulate matter and carbon monoxide (CO) are deleterious to health for example their exposure has been associated with heart attacks, wheezing, coughing, asthma, still births and lung cancer $[2,12,13]$. Particulate matter (PM) consists of a mixture of solid and liquid particles suspended in the air for extended periods of time [7]. Solid particulates are composed of those with a diameter of less than $2.5 \mu \mathrm{m}\left(\mathrm{PM}_{2.5}\right)$, often called fine PM, and those with a diameter of less than $0.1 \mu \mathrm{m}$ called ultra-fine particles [14]. They can penetrate deeper into respiratory tract leading to respiratory failure [15], hence the concern on possible hazardous effect on health if inhaled.

In addition to the size of particulate matter, its components such as heavy metals are among the risk factors to human health and studies have shown a higher concentration of these metals in indoor air compared to outdoor air [16]. The toxic metal content of $\mathrm{PM}_{2.5}$ has been associated with adverse respiratory health effects according to the International Agency for Research on Cancer (IARC), which classified several metals, including chromium, cadmium, lead and nickel, as potential cancer causing agents $[7,17]$ showing the need to determine heavy-metal composition in particulate matter.

Ambient air quality affects indoor air and indoor air has been found to contain higher concentrations of pollutants compared to outdoor air [18, 19]; High ambient air pollution levels have been reported in North Africa and Southeast Asia [20] and there is evidence that air quality in some African cities like Lagos in Nigeria, is deteriorating where $\mathrm{PM}_{2.5}$ concentrations have been estimated at $100 \mathrm{mg} / \mathrm{m}^{3}$ compared to $<20 \mathrm{mg} / \mathrm{m}^{3}$ in most European and North American cities [21]; there is need for air quality monitoring in African cities.

Apart from ambient air quality activities occurring indoors also influence the air quality; for example BTEX was found in indoor air of beauty salons in Iran [22]. In a study investigating $\mathrm{PM}_{2.5}$ in urban homes in Egypt a correlation was observed between kitchen activities (smoking and cooking) and $\mathrm{PM}_{2.5}$ levels [23] and variations in cooking fuel and kitchen size produced large differences in indoor air pollution in rural Madagascar [24]. In this study kitchen characteristics like the wall, floor and roof types in addition to the volume and fuel used were investigated to better understand their effect on indoor air quality.

Although there is limited information about air quality in Uganda, the 2018 world air quality report ranked Uganda, second after Nigeria among the African countries with worst particulate matter pollution [25]. An assessment of outdoor air in two Ugandan cities (Kampala and Jinja) indicated the mean $\mathrm{PM}_{2.5}$ concentration $\left(132.1 \mu \mathrm{g} / \mathrm{m}^{3}\right)$ as 5.5 times higher than the WHO cut-off limits of $24 \mu \mathrm{g} / \mathrm{m}^{3}$ [26]. Higher concentrations of $\mathrm{PM}_{2.5}$ were observed in Kampala compared to Jinja and this was attributed to dust emission from unpaved roads, high traffic and industrial emissions, and burning of household garbage. The limited air quality information in Uganda and the scarcity of data on indoor air quality motivated this investigation in Mbarara Municipality.

In Mbarara town $77.3 \%$ of population depends on charcoal fuel [27] and the town is the second to Kampala in industry. The increasing small-scale industries and biomass use in Mbarara can generate hazardous air pollutants thus a need for air quality monitoring in Mbarara. Furthermore, since outdoor air can influence indoor air, there was need to assess indoor air quality because the World Health Organization (WHO) ranks indoor air pollution (from biomass fuel combustion) and urban outdoor air pollution 10th and 14th, respectively, among 19 leading risk factors for global mortality [28]. This study therefore determined particulate matter, its metal components, and carbon monoxide concentrations from households using biomass energy in Mbarara Municipality to evaluate the contribution of charcoal biomass to indoor air pollution.

\section{Materials and methods}

\subsection{Study site}

The study was conducted in Mbarara Municipality western Uganda (Fig. 1), about $270 \mathrm{~km}$, by road, southwest of Kampala, Uganda's capital city. Mbarara Municipality is divided into six divisions which include Biharwe, Nyakayojo, Kakiika, Kakoba, Kamukuzi and Nyamitanga. In August 2014 , the national population census put the population at 195,013 [29]. 


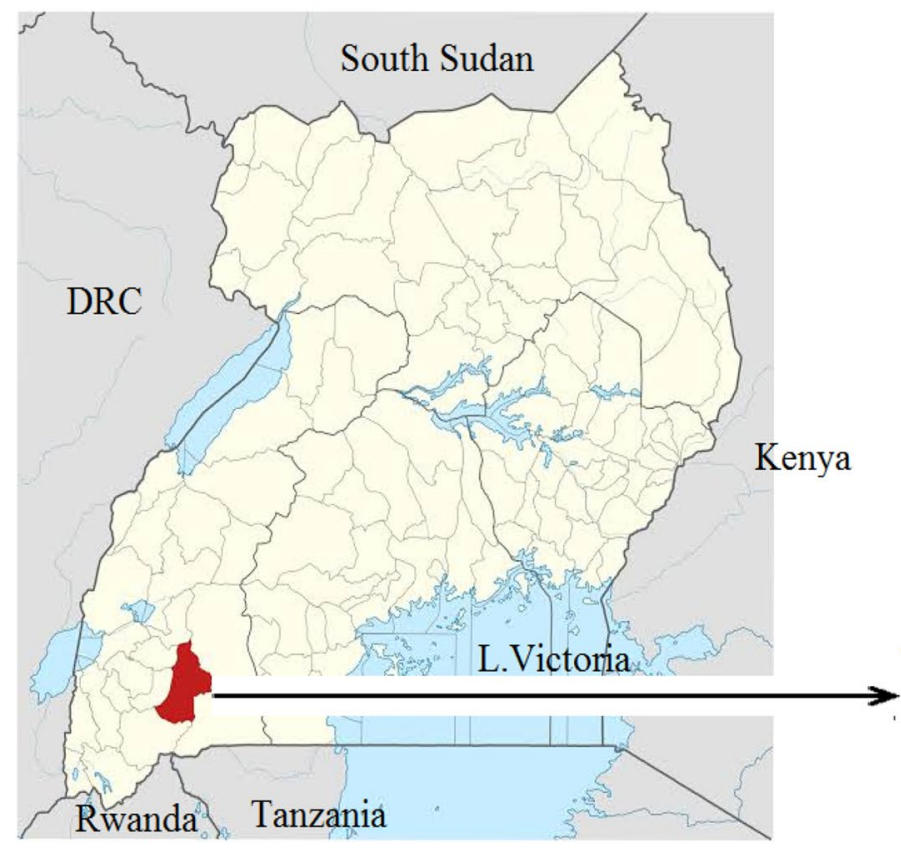

Mbarara Municipality

Fig. 1 Map showing Mbarara Municipality—the study area

\subsection{Study design}

This was a descriptive and experimental study which described kitchen characteristics and determined indoor particulate matter $\mathrm{PM}_{2.5}$, its heavy metal composition and $\mathrm{CO}$ in kitchens that use charcoal as their main cooking fuel Mbarara Municipality. The study was conducted between December 2017 and April 2018 in six villages randomly selected from the six divisions of Mbarara Municipality. $\mathrm{PM}_{2.5}$ and its heavy metal content were measured in December 2017 (dry season, with average rainfall $76 \mathrm{~mm}$ ) and in February, March and April 2018 (wet season, with average rainfall $132 \mathrm{~mm}$ ). CO in household kitchens was measured from February to April 2018. Sixty households (10 from each village) which use charcoal as their main source of energy were selected for the study, and permission to install devises for measuring the pollutants in households was obtained from family heads.

\subsection{Sample size determination}

Sample size was determined using a formula by Smith (2013) [30] as shown in Eq. (1)

$n=\frac{Z^{2} \sigma^{2}}{B^{2}}$

where $\mathrm{n}=$ sample size

$$
\begin{aligned}
& Z=Z \text {-score }(1.96) \\
& \sigma=\text { standard deviation }(0.198) \\
& B=\text { margin of error }(0.05)
\end{aligned}
$$

The study was described to all participating households and informed consents for participation were secured. Ethical approval was sought and obtained from Mbarara University of Science and Technology Research and Ethics Committee (MUREC1/7). The study used interviews, focus group discussions, self-administered questionnaires, indoor air monitors, and ICP-OES to obtain qualitative and quantitative data.

\subsection{Determination of household demographics and kitchen characteristics}

A questionnaire was administered to each of the family heads to obtain data about house demographics and kitchen characteristics. The questionnaire was pretested before the main study among ten randomly selected houses to correct method errors and was administered in both English and Runyankore (the local language spoken in Mbarara). In addition to questionnaires, six focus group discussions (FGDs) consisting of family heads were conducted in each of the selected cells to interrogate the data obtained by questionnaires about house characteristics. All FGDs consisted between six to seven participants and discussions were conducted in the local language (Runyankole). 


\subsection{Determination of $\mathrm{PM}_{2.5}$ in indoor air of kitchens using charcoal as the main source of energy}

Indoor concentrations of fine particulate matter $\left(\mathrm{PM}_{2.5)}\right.$ and temperature were measured following the method described by Balakrishnan et al. [31], using University of California Berkeley Particle and Temperature Sensor (UCBPATS, Berkeley Air Monitoring Group, Berkeley, CA, USA) with size-selective in-let conditioner. Monitors were placed at a height of $1.5 \mathrm{~m}$ above the ground and $1 \mathrm{~m}$ from the point of cooking which is within the breathing range of a person seated while cooking. They were calibrated with combustion aerosols of charcoal against gravimetric measurements of $\mathrm{PM}_{2.5}$ in the laboratory before being used in the field. Particle coefficients were derived for each instrument in the field through colocation of UCB-PATs monitors and gravimetric samplers with a flow rate of $1.5 \mathrm{~L} / \mathrm{min}$. Each participating household was monitored for $24 \mathrm{~h}$.

Using a laboratory calibrated rota meter, flow rates were measured before and after sampling. The in-lets drew $\mathrm{PM}_{2.5}$ onto cellulose/PTFE collection filters fitted in the cyclones of size-selective in-lets of diameter $2.5 \mu \mathrm{m}$ connected to the sampler. The filters were conditioned in a temperature and humidity controlled room for $24 \mathrm{~h}$ before weighing. The filters were then weighed three times each before and after sample collection using a micro balance (Metler Toledo XS3DU) in a temperature and humidity controlled room and average values of $\mathrm{PM}_{2.5}$ were calculated. PM samples were then stored in plastic petri-dishes at $20^{\circ} \mathrm{C}$ in a refrigerator before analyzing them for heavy metals.

The UCB-PATS were first kept in ziplock bags for $1 \mathrm{~h}$ to allow the monitor adjust itself to measure zero particulate matter before and after deployment. After monitoring, all data files were batch-processed using a customized software package developed for this device [31].

\subsection{Determination of heavy metals in $\mathrm{PM}_{2.5}$ collected from kitchens using charcoal as the main source of energy}

\subsubsection{Sample collection and preparation}

Particulate matter was collected on filters as described in section 2.5 (Determination of $\mathrm{PM}_{2.5}$ in Indoor Air of Kitchens Using Charcoal). A procedure recommended by U.S. Environmental Protection Agency (EPA/625/R96/110a) was used as the conventional acid extraction method to extract metals from the filters. Nitric acid (1 M) was added to a filter in a digestion glass vial. The sample was then heated at $90{ }^{\circ} \mathrm{C}$ for $15 \mathrm{~min}$. Concentrated nitric acid $(2.5 \mathrm{~mL})$ was then added, and the sample refluxed for another $30 \mathrm{~min}$. The sample was then cooled and concentrated nitric acid $(2.5 \mathrm{~mL})$ added again. The sample was refluxed for an additional $30 \mathrm{~min}$. This was followed by addition of $30 \%$ hydrogen peroxide $(0.5 \mathrm{~mL})$ to the cool sample and the sample re-heated until no effervescence. Hydrogen peroxide $(1.0 \mathrm{~mL})$ was then added to the sample three more times and sample heated between each aliquot addition of $30 \%$ hydrogen peroxide. After cooling, the sample was diluted up to $50 \mathrm{~mL}$ with deionized water. The procedure was repeated for each of the filters from the households studied.

\subsubsection{ICP-OES analytical method validation}

Calibration solutions were prepared by diluting standard metal solutions to concentrations of $0.1 \mathrm{mg} / \mathrm{L}, 1.0 \mathrm{mg} / \mathrm{L}$, $2.0 \mathrm{mg} / \mathrm{L}, 20.0 \mathrm{mg} / \mathrm{L}$ and the machine was checked after the initial calibration for every ten samples. In the case of more than $\pm 10 \%$ deviation, the ICP-OES ( 8300 Perkin Elmer, USA) would be re-calibrated. The limit of detection (LOD) for each element was obtained from, $L O D=3 \mathrm{~S} / \mathrm{m}$, where $S$ is the standard deviation of the blank readings and $m$ represents the gradient of the calibration curve for each element. The limit of quantification (LOQ) was calculated using $\mathrm{LOQ}=10 \mathrm{~S} / \mathrm{m}$.

\subsubsection{Analysis for metals in $\mathrm{PM}_{2.5}$}

The samples were analyzed using an Inductively Coupled Plasma Optical Emission Spectrometer (ICP-OES). A tube connected to the ICP-OES was dipped into each sample to aspirate the sample into the machine which would analyze and produce the analyte concentration. The average concentration for triplicate measurements for a particular sample was then computed.

\subsection{CO monitoring in indoor air of kitchens using charcoal as the main source of energy}

Carbon monoxide concentrations were measured using a portable, battery-operated, data-logging Drager Pac 7000 (SKC, Inc.; Eighty-Four, PA, USA) placed at a height of $1.5 \mathrm{~m}$ above the ground and $1 \mathrm{~m}$ from the point of cooking. The Pac 7000 recorded and logged the peak concentration that occurred within each minute during the monitoring period following the method described by Balakrishnan et al. (2015) [31]. Each participating household was monitored for $24 \mathrm{~h}$.

\subsection{Data analysis}

Data was collected, tabulated and entered into Microsoft Excel. Means, variance and standard error were used to assess the spread of the data. The mean of parameters 
$( \pm \mathrm{SE})$ and one-way analysis of variance (ANOVA) were used to compare the mean values of observations. Differences in mean values were considered significant if calculated $p$-values were $<0.05$.

\section{Results and discussion}

\subsection{Household demographics and kitchen characteristics}

Information on household demographics and kitchen characteristics is summarized in Table 1. The average number of people living in each house was $3.6 \pm 1.5$ which is in agreement with the national average of 4.0 [32] and there were no smoking occupants in all households investigated in this study. Some of the households (37\%) were renting and some houses had no kitchens which influenced cooking from the main house. $43.3 \%$ of household owners attained primary education $38.3 \%$ secondary education and $15 \%$ degree and $3.3 \%$ attained diplomas.

Kitchen volumes ranged from 12 to $81 \mathrm{~m}^{3}$ and their roofs $(96.6 \%)$ were metallic while only $3.4 \%$ were concrete. Kitchen walls were made of mud (5\%), wood $(20 \%)$ or concrete (74\%) and floors were wood (3.4\%), mud (41\%), and cement (56\%). $23 \%$ of the respondents did not open doors while cooking but only $3.4 \%$ did not open doors. $22 \%$ of the houses studied were located near the road and only $6.8 \%$ showed cross ventilation. $21 \%$ of the respondents cooked from the main house and $79 \%$ used kitchens.

Charcoal was the most commonly used cooking fuel and this was corroborated during focus groups discussions. There was high demand for charcoal compared to wood; other fuels like electricity and paraffin were considered to be expensive. Participants in the focus group discussion also stated that financial status and lack of kitchens determined the type of fuels used. When asked "why do people in Mbarara Municipality use different fuels?" for example one respondent said:

for me I don't have a kitchen...I cook from where I sleep, how can I use wood? Wood even produces a lot of smoke which can darken the walls and my clothes.

Two participants revealed that they use paraffin stoves only when they do not have enough time to light charcoal stoves.

Responding to the question "How do you light charcoal?", $58 \%$ said they use wood husks or papers, $30 \%$ use polythene papers, $5 \%$ use paraffin and others were undecided. The method used to light charcoal can contribute to kitchen indoor pollutants for example; burning of polythene papers has been associated with heavy metal emission [33].

Most of the focus group participants (73.7\%) responded positively when asked "Do you believe in opening windows and doors while cooking?" These participants associated window and door opening with circulation of fresh and cool air into kitchens but had no knowledge about the other effects of outdoor air on indoor air like transfer of pollutants from ambient air into indoor air. Some participants however were opposed to the opening of windows and doors during cooking because they did not want people to know that they cook and they believed that charcoal does not produce a lot of smoke which would require opening kitchen windows. For example, one participant said:

for me I don't see the importance of opening the widows... what if it is raining or at night...you cannot. May be if there is no electric power I can open to get light

This shows limited knowledge on the importance of kitchen ventilation on air circulation.

All participants recommended the kitchen as the best place to cook from when responding to the question "What is the best place to cook from?" but they gave varying views when responding to the question "Why do people cook from the main house and not in kitchens?". Some attributed the cooking from main house to financial status, for example one participant said in a sad tone:

I have failed to pay rent for the main house. Can I manage to pay for another room to be used as a kitchen? It is not possible.

Other people attributed cooking from the main house to limited space, for example one participant said: "usually there is no enough space and even the little space available you are planning to build another room for renting". Financial status is a limiting factor to possession of kitchens although it was also revealed during the discussions that some people were renting and even if they had money to construct kitchens, they were unable to.

All focus group participants were in agreement that kitchen air can be contaminated when responding to the question "Do you agree that kitchen indoor air can be contaminated?"They revealed that cooking and sweeping are the common sources of kitchen air pollutants when asked "What could be the sources of kitchen air contaminants?". For example, one participant said:

When you are lighting charcoal stove, the wood husks you are using produce a lot of smoke. In fact sometimes I am forced to light it from outside to reduce on the smoke in the kitchen. 


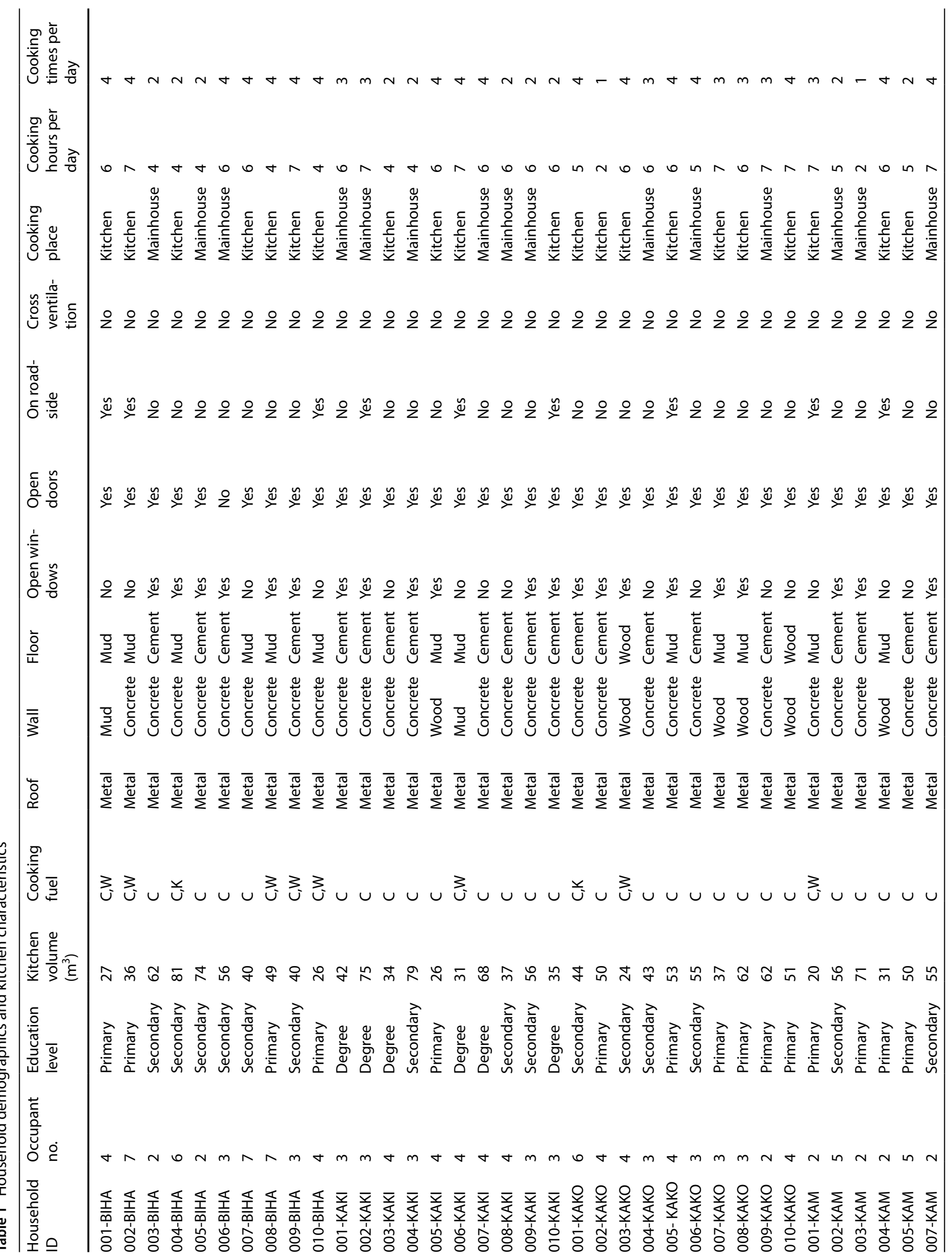




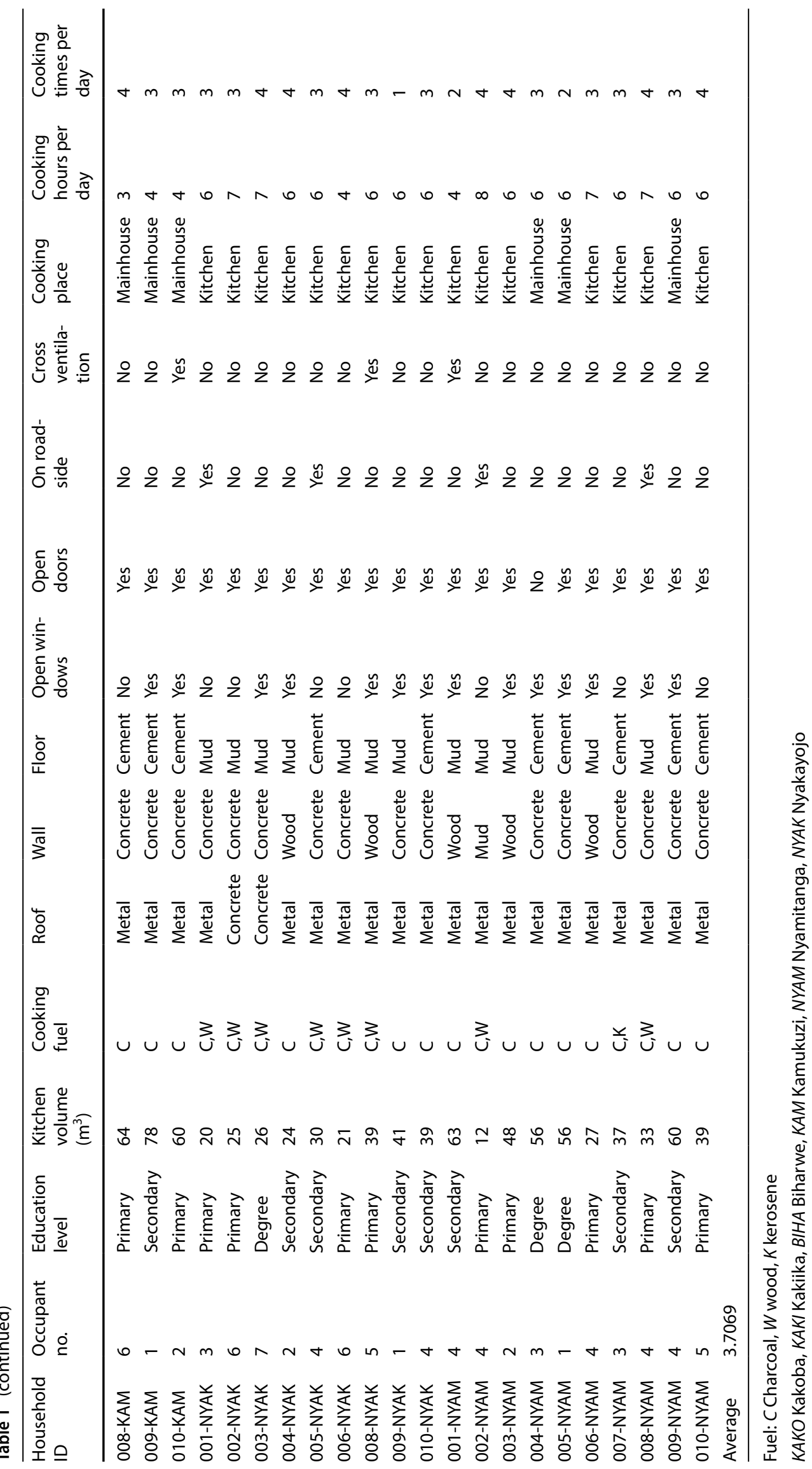


From the discussions, the participants demonstrated awareness about some indoor air pollutants although knowledge about the outdoor sources of pollutants like nearby traffic and industrial emissions was limited. Participants were also aware of some effects of kitchen smoke; responding to the question "What could be the effects of kitchen smoke?" Most responses were about eye irritation, staining/darkening of clothes and kitchen walls by the smoke. Participants had limited knowledge on other health effects of kitchen smoke inhalation like lung cancer and pneumonia.

Focus group discussions generated richer data that supplemented the data collected by interviews and selfadministered questionnaires; for example, the large number of people cooking from main house which was generated by questionnaires was attributed to financial status by the focus groups discussions. It was also revealed that participants had little information about indoor air pollution while some seemed unbothered.

\subsection{Mean $24 \mathrm{~h}$ indoor $\mathrm{PM}_{2.5}$ concentration in different kitchens in Mbarara Municipality}

During the 2017 survey, 60 households were monitored however only 58 households were present in the followup 2018 survey because two households shifted. Kitchen concentrations of $\mathrm{PM}_{2.5}$ are reported in Table 2.

Nyakayojo had the highest average indoor concentration of $\mathrm{PM}_{2.5}\left(0.84 \mathrm{mg} / \mathrm{m}^{3}\right)$ while Kamukuzi had the least average concentration of $\mathrm{PM}_{2.5}\left(0.29 \mathrm{mg} / \mathrm{m}^{3}\right)$ in both dry season and wet season as shown in Table 3. This can be attributed to the kitchen characteristics like mud floors and supplementing charcoal with wood fuel which were predominant in Nyakayojo. On average, there was a significant difference in $\mathrm{PM}_{2.5}$ concentration across all divisions $(p=0.004)$ due to differences in fuels used to supplement charcoal and other kitchen characteristics like size and floor type.

The mean 24-h particulate matter concentration was higher than the World Health Organization (WHO) 24-h Air Quality Guideline of $0.024 \mathrm{mg} / \mathrm{m}^{3}$ (Tables 2 and 3 and Fig. 2). This shows that charcoal fuel contributes to pollution of indoor air in kitchens in Mbarara Municipality. Higher $\mathrm{PM}_{2.5}$ concentrations have also been observed in other studies in rural Sierra Leone where an average of $1.686 \mathrm{mg} / \mathrm{m}^{3}$ was observed in kitchens using charcoal fuel [34]. However, some studies have observed lower concentrations than observed e.g. a study assessing indoor air in urban slums of Nairobi found $\mathrm{PM}_{2.5}$ concentration of $0.1265 \mathrm{mg} / \mathrm{m}^{3}$ [35]. These differences can be attributed to locations of kitchens in these studies like being near emission sources $[19,24]$ in addition to kitchen characteristics
Table 2 Mean $24 \mathrm{~h}$ indoor $\mathrm{PM}_{2.5}$ concentrations in indoor air of kitchen in Mbarara Municipality

\begin{tabular}{|c|c|c|c|}
\hline Household ID & $\begin{array}{l}\mathrm{PM}_{2.5} \text { concentra- } \\
\text { tion }\left(\mathrm{mg} / \mathrm{m}^{3}\right) \text { dry } \\
\text { season }\end{array}$ & $\begin{array}{l}\mathrm{PM}_{2.5} \text { concentra- } \\
\text { tion }\left(\mathrm{mg} / \mathrm{m}^{3}\right) \text { wet } \\
\text { season }\end{array}$ & Division \\
\hline 001-BIHA & $1.831 \pm 0.0003$ & $1.615 \pm 0.0026$ & Biharwe \\
\hline 002-BIHA & $1.324 \pm 0.0003$ & $0.504 \pm 0.0050$ & Biharwe \\
\hline 003-BIHA & $0.001 \pm 0.0003$ & $0.073 \pm 0.0018$ & Biharwe \\
\hline 004-BIHA & $0.043 \pm 0.0003$ & $0.041 \pm 0.0015$ & Biharwe \\
\hline 005-BIHA & $0.055 \pm 0.0003$ & $0.046 \pm 0.0011$ & Biharwe \\
\hline 006-BIHA & $0.160 \pm 0.0005$ & $0.140 \pm 0.0008$ & Biharwe \\
\hline 007-BIHA & $0.928 \pm 0.0005$ & $0.555 \pm 0.0011$ & Biharwe \\
\hline 008-BIHA & $0.917 \pm 0.0003$ & $0.571 \pm 0.0003$ & Biharwe \\
\hline 009-BIHA & $0.885 \pm 0.0001$ & $0.518 \pm 0.0017$ & Biharwe \\
\hline 010-BIHA & $0.736 \pm 0.0001$ & $0.763 \pm 0.0011$ & Biharwe \\
\hline 001-KAKI & $0.169 \pm 0.0001$ & $0.127 \pm 0.0029$ & Kakiika \\
\hline 002-KAKI & $0.164 \pm 0.0001$ & $0.093 \pm 0.0012$ & Kakiika \\
\hline 003-KAKI & $0.515 \pm 0.0042$ & $0.522 \pm 0.0011$ & Kakiika \\
\hline 004-KAKI & $0.072 \pm 0.0014$ & $0.058 \pm 0.0007$ & Kakiika \\
\hline 005-KAKI & $0.881 \pm 0.0004$ & $0.764 \pm 0.0007$ & Kakiika \\
\hline 006-KAKI & $1.486 \pm 0.0007$ & $1.524 \pm 0.0017$ & Kakiika \\
\hline 007-KAKI & $0.217 \pm 0.0035$ & $0.185 \pm 0.0016$ & Kakiika \\
\hline 008-KAKI & $0.335 \pm 0.0002$ & $0.236 \pm 0.0014$ & Kakiika \\
\hline 009-KAKI & $0.328 \pm 0.0005$ & $0.330 \pm 0.0006$ & Kakiika \\
\hline 010-KAKI & $0.732 \pm 0.0003$ & $0.679 \pm 0.0016$ & Kakiika \\
\hline 001-KAKO & $0.089 \pm 0.0015$ & $0.051 \pm 0.0017$ & Kakoba \\
\hline 002-KAKO & $0.269 \pm 0.0022$ & $0.079 \pm 0.0002$ & Kakoba \\
\hline 003-KAKO & $0.731 \pm 0.0010$ & $0.982 \pm 0.0013$ & Kakoba \\
\hline 004-KAKO & $0.155 \pm 0.0010$ & $0.162 \pm 0.0010$ & Kakoba \\
\hline 005-КАКО & $0.338 \pm 0.0020$ & $0.524 \pm 0.0009$ & Kakoba \\
\hline 006-КАКО & $1.003 \pm 0.0021$ & $0.507 \pm 0.0057$ & Kakoba \\
\hline 007-KAKO & $0.291 \pm 0.0007$ & $0.272 \pm 0.0011$ & Kakoba \\
\hline 008-KAKO & $0.042 \pm 0.0006$ & $0.053 \pm 0.0006$ & Kakoba \\
\hline 009-КАКО & $0.078 \pm 0.0006$ & $0.092 \pm 0.0007$ & Kakoba \\
\hline 010-КАKO & $0.077 \pm 0.0001$ & $0.187 \pm 0.0005$ & Kakoba \\
\hline 001-KAM & $1.285 \pm 0.0011$ & $1.203 \pm 0.0010$ & Kamukuzi \\
\hline 002-KAM & $0.044 \pm 0.0016$ & $0.045 \pm 0.0006$ & Kamukuzi \\
\hline 003-KAM & $0.035 \pm 0.0007$ & $0.041 \pm 0.0013$ & Kamukuzi \\
\hline 004-KAM & $0.883 \pm 0.0007$ & $0.574 \pm 0.0005$ & Kamukuzi \\
\hline 005-KAM & $0.007 \pm 0.0005$ & $0.040 \pm 0.0007$ & Kamukuzi \\
\hline 006-KAM & $0.036 \pm 0.0007$ & $0.045 \pm 0.0014$ & Kamukuzi \\
\hline 007-KAM & $0.137 \pm 0.0011$ & $0.187 \pm 0.0015$ & Kamukuzi \\
\hline 008-KAM & $0.332 \pm 0.0011$ & $0.297 \pm 0.0003$ & Kamukuzi \\
\hline 009-KAM & $0.037 \pm 0.0004$ & $0.051 \pm 0.0008$ & Kamukuzi \\
\hline 010-KAM & $0.064 \pm 0.0006$ & $0.031 \pm 0.0010$ & Kamukuzi \\
\hline 001-NYAK & $0.424 \pm 0.0006$ & $0.712 \pm 0.0011$ & Nyakayojo \\
\hline 002-NYAK & $1.706 \pm 0.0008$ & $1.449 \pm 0.0008$ & Nyakayojo \\
\hline 003-NYAK & $1.895 \pm 0.0006$ & $1.391 \pm 0.0032$ & Nyakayojo \\
\hline 004-NYAK & $0.850 \pm 0.0065$ & $0.561 \pm 0.0061$ & Nyakayojo \\
\hline 005-NYAK & $1.155 \pm 0.0017$ & $1.158 \pm 0.0008$ & Nyakayojo \\
\hline 006-NYAK & $0.754 \pm 0.0168$ & $0.518 \pm 0.0017$ & Nyakayojo \\
\hline 007-NYAK & $0.301 \pm 0.0011$ & $0.202 \pm 0.0014$ & Nyakayojo \\
\hline
\end{tabular}


Table 2 (continued)

\begin{tabular}{llll}
\hline Household ID & $\begin{array}{l}\mathrm{PM}_{2.5} \text { concentra- } \\
\text { tion }\left(\mathrm{mg} / \mathrm{m}^{3}\right) \text { dry } \\
\text { season }\end{array}$ & $\begin{array}{l}\mathrm{PM}_{2.5} \text { concentra- } \\
\text { tion }\left(\mathrm{mg} / \mathrm{m}^{3}\right) \text { wet } \\
\text { season }\end{array}$ & Division \\
\hline 008-NYAK & $0.321 \pm 0.0045$ & $0.304 \pm 0.0029$ & Nyakayojo \\
009-NYAK & $0.345 \pm 0.0049$ & - & Nyakayojo \\
010-NYAK & $0.631 \pm 0.0002$ & - & Nyakayojo \\
001-NYAM & $0.038 \pm 0.0011$ & $0.043 \pm 0.0003$ & Nyamitanga \\
002-NYAM & $1.519 \pm 0.0077$ & $1.527 \pm 0.0024$ & Nyamitanga \\
003-NYAM & $0.984 \pm 0.0023$ & $0.805 \pm 0.0027$ & Nyamitanga \\
004-NYAM & $0.728 \pm 0.0020$ & $0.602 \pm 0.007$ & Nyamitanga \\
005-NYAM & $0.016 \pm 0.0004$ & $0.028 \pm 0.0006$ & Nyamitanga \\
006-NYAM & $0.113 \pm 0.0008$ & $0.120 \pm 0.0005$ & Nyamitanga \\
007-NYAM & $0.682 \pm 0.0021$ & $0.603 \pm 0.0009$ & Nyamitanga \\
008-NYAM & $0.843 \pm 0.0035$ & $0.851 \pm 0.0006$ & Nyamitanga \\
009-NYAM & $0.107 \pm 0.0030$ & $0.082 \pm 0.0009$ & Nyamitanga \\
010-NYAM & $0.428 \pm 0.0080$ & $0.324 \pm 0.0085$ & Nyamitanga \\
Average & 0.526 & 0.449 & \\
\hline
\end{tabular}

Table 3 Mean $24 \mathrm{~h}$ indoor PM2.5 concentrations per division in Mbarara Municipality

\begin{tabular}{lll}
\hline Division & $\mathrm{PM}_{2.5}\left(\mathrm{mg} / \mathrm{m}^{3}\right)$ & \\
\cline { 2 - 3 } & Dry season & Wet season \\
\hline Biharwe & 0.688 & 0.483 \\
Nyakayojo & 0.838 & 0.787 \\
Kakiika & 0.490 & 0.452 \\
Kakoba & 0.307 & 0.291 \\
Kamukuzi & 0.286 & 0.252 \\
Nyamitanga & 0.546 & 0.498 \\
\hline
\end{tabular}

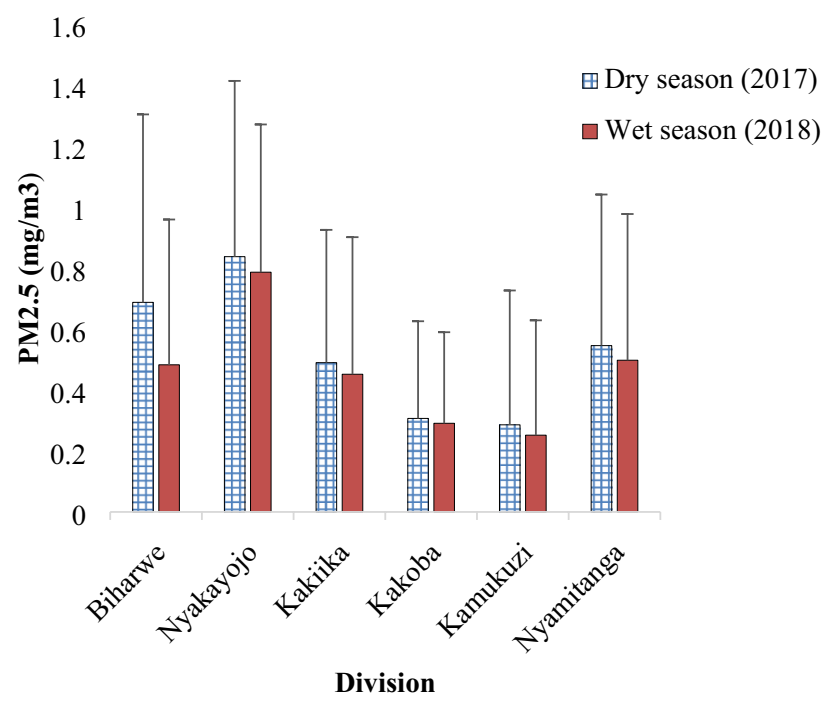

Fig. 2 Mean $24 \mathrm{~h} \mathrm{PM}_{2.5}$ concentration per division for dry season and wet season such as ventilation and use of other fuels in addition to charcoal may affect the quantity of PM.

\subsection{Influence of household demographics on $\mathrm{PM}_{2.5}$ concentrations}

Most household owners attained primary education (43.3\%) followed by secondary education (38.3\%), diploma $(03 \%)$, and then degree (15\%) indicating low literacy levels in the area. Households where family heads attained degree had higher mean $\mathrm{PM}_{2.5}$ concentration $\left(0.62 \mathrm{mg} / \mathrm{m}^{3}\right)$ followed by primary education $\left(0.59 \mathrm{mg} / \mathrm{m}^{3}\right)$ then secondary $\left(0.336 \mathrm{mg} / \mathrm{m}^{3}\right)$ and lastly diploma $\left(0.15 \mathrm{mg} / \mathrm{m}^{3}\right)$. This is because most households with graduate heads cooked for a long period (6-7 h) leading to which generation of more of the pollutant compared to other households like those with diploma that cooked for a short period (3-4 h). During focus group discussions, long hours of cooking was attributed to cooking foods like meat and beans which take long to be ready and leaving fire on to keep food warm.

The mean $\mathrm{PM}_{2.5}$ concentration was higher in households with seven occupants $\left(1.01 \mathrm{mg} / \mathrm{m}^{3}\right)$ followed by those with four $\left(0.66 \mathrm{mg} / \mathrm{m}^{3}\right)$, then households with six $\left(0.52 \mathrm{mg} / \mathrm{m}^{3}\right)$ followed by those with two $(0.39 \mathrm{mg} /$ $\left.\mathrm{m}^{3}\right)$, three $\left(0.38 \mathrm{mg} / \mathrm{m}^{3}\right)$, five $\left(0.19 \mathrm{mg} / \mathrm{m}^{3}\right)$ and lowest in households with one occupant $\left(0.14 \mathrm{mg} / \mathrm{m}^{3}\right)$. On average, there was a significant difference in $\mathrm{PM}_{2.5}$ concentration across all households with different number of occupants $(p=0.01)$. This was expected because of the observed differences in cooking times in different households. Households with one occupant cooked once or twice a day implying that less amounts of the pollutant were produced compared to other households that cooked many times a day. Also, households with many occupants cooked for longer hours which can be attributed to food prepared that require longer hours to be ready. The mean $\mathrm{PM}_{2.5}$ concentration in households with five occupants was lower than that for those with four occupants. This is because $25 \%$ of households with five occupants had mud floors that generated less $\mathrm{PM}_{2.5}$ concentration compared to households with four occupants where $44.4 \%$ had mud floor that generated much $\mathrm{PM}_{2.5}$ concentration.

\subsection{Influence of kitchen characteristics on $\mathrm{PM}_{2.5}$ concentrations}

It was observed that more kitchens supplemented charcoal fuel with wood (26.3\%) than kerosene $(5.3 \%)$ as shown in Table 1. The results are similar to those observed in a similar study conducted in Korogocho a Nairobi slum where a larger percentage of households (62.5\%) used charcoal and wood compared to that using kerosene 
(12.5\%) [35] and this is attributed to high prices of kerosene compared to other fuels. This supports results from a study which classified wood and charcoal as most important sources of energy in most African cities [4, 6, 36]. A large number of households (39.5\%) cooked from rooms used for sleeping which increases their exposure to indoor air pollutants. Most households cooked with either windows or doors closed which limits ventilation yet poor ventilation affects air quality [37] and this could increase exposure levels to indoor air pollutants.

\subsubsection{Influence of kitchen size on $\mathrm{PM}_{2.5}$ concentration}

The average kitchen volume was $46 \pm 17 \mathrm{~m}^{3}$. Increase in kitchen volume decreases $\mathrm{PM}_{2.5}$ concentrations as shown by a negative significant correlation between $\mathrm{PM}_{2.5}$ concentration and kitchen volume $(r=-0.7 ; p=0.000)$. This is because increased kitchen sizes can allow quick dilution, circulation and exit of polluted air from kitchens and this reduces exposure level to $\mathrm{PM}_{2.5}$.

\subsubsection{Effect of cooking fuel on indoor $\mathrm{PM}_{2.5}$ concentrations}

Kitchens using charcoal and wood had higher $\mathrm{PM}_{2.5}$ concentrations $\left(1.044 \mathrm{mg} / \mathrm{m}^{3} \pm 0.46\right)$ compared to those using charcoal only $\left(0.284 \mathrm{mg} / \mathrm{m}^{3} \pm 0.28\right)$ showing that wood contributed to $\mathrm{PM}_{2.5}$ concentrations in indoor air. There was no significant difference between $\mathrm{PM}_{2.5}$ concentrations in kitchens using charcoal only and those using both charcoal and kerosene $(p=0.972)$ and this can be attributed to irregular use of kerosene indicated in focus group discussions. On average, there was a significant difference in $\mathrm{PM}_{2.5}$ concentration across all the cooking fuel types $(p=0.00)$. This was expected since different fuel types have different components. All the cooking fuel types produced $\mathrm{PM}_{2.5}$ concentrations that were higher than the WHO recommended levels which exposes households to harmful effects of $\mathrm{PM}_{2.5}$.

\subsubsection{Effect of roofing material on indoor $\mathrm{PM}_{2.5}$ concentrations}

Many kitchens (56) had metal roofs and only two had concrete roofs and the observed $\mathrm{PM}_{2.5}$ concentration was higher $\left(1.8 \mathrm{mg} / \mathrm{m}^{3}\right)$ in the few kitchens with concrete roof than in those with metal roof $\left(0.52 \mathrm{mg} / \mathrm{m}^{3}\right)$. Metal roofs had some vents that could have allowed quick circulation and exchange of air pollutants reducing their concentrations in indoor air compared to concrete roofs which did not have vents resulting into high $\mathrm{PM}_{2.5}$ concentrations. Also, most of concrete roofs were not smooth and in wearing off condition, hence could have generated indoor air pollutants raising their concentration in indoor air. $\mathrm{PM}_{2.5}$ concentration was higher $\left(1.61 \mathrm{mg} / \mathrm{m}^{3}\right)$ in kitchens with mud floor and concrete roof than in those with mud floor and metal roof $\left(0.77 \mathrm{mg} / \mathrm{m}^{3}\right)$ indicating increased pollution in kitchens with concrete roofs. Therefore, there is need to allow more ventilation in kitchens with concrete roofs to enable quick air exchange of indoor air pollutants and smoothening of concrete to reduce on wearing off.

\subsubsection{Effect of kitchen wall on indoor $\mathrm{PM}_{2.5}$ concentrations}

Kitchens with mud walls had higher $\mathrm{PM}_{2.5}$ concentration $\left(1.6 \mathrm{mg} / \mathrm{m}^{3}\right)$, followed by concrete walls $\left(0.48 \mathrm{mg} / \mathrm{m}^{3}\right)$, then wood $\left(0.47 \mathrm{mg} / \mathrm{m}^{3}\right)$ as shown in Table 1. Also, kitchens with mud floor and mud wall had higher $\mathrm{PM}_{2.5}$ concentration $\left(1.8 \mathrm{mg} / \mathrm{m}^{3}\right)$, followed by mud floor with concrete walls $\left(0.8 \mathrm{mg} / \mathrm{m}^{3}\right)$, then mud floor with wood wall $\left(0.44 \mathrm{mg} / \mathrm{m}^{3}\right)$. This shows that wood wall was better than mud and concrete walls (which were in poor condition). The high $\mathrm{PM}_{2.5}$ concentration in kitchens with mud and concrete walls can be attributed to high rate of wearing off of the walls observed in most kitchens compared to wood. Also, during cleaning, air pollutants can be generated much more from concrete and mud which were observed to have a high rate of wearing off compared to wood. Concrete kitchens should be cleaned gently to reduce on the rate of wearing off.

\subsubsection{Effect of kitchen floor on indoor $\mathrm{PM}_{2.5}$ concentrations}

Kitchens with mud floors had higher $\mathrm{PM}_{2.5}$ concentration $\left(0.83 \mathrm{mg} / \mathrm{m}^{3}\right)$, followed by wood floor $\left(0.4 \mathrm{mg} / \mathrm{m}^{3}\right)$, followed by cement $\left(0.30 \mathrm{mg} / \mathrm{m}^{3}\right)$. High $\mathrm{PM}_{2.5}$ concentration in kitchens with mud floors is as a result of sweeping where mud floors generate a lot of dust compared to other floors. This is supported by information generated from focus group discussions where most house owners reported that they sweep daily. Therefore controlled sweeping by first applying some water to reduce on dust is recommended.

\subsubsection{Effect of ventilation on indoor $\mathrm{PM}_{2.5}$ concentrations}

Kitchens that cooked with windows and doors open had lower $\mathrm{PM}_{2.5}$ concentration $\left(0.37 \mathrm{mg} / \mathrm{m}^{3}\right)$ than those that cooked with windows and doors closed $\left(0.78 \mathrm{mg} / \mathrm{m}^{3}\right)$. On average, there was a significant difference in $\mathrm{PM}_{2.5}$ concentration across kitchens with closed and open windows $(p=0.002)$ as expected since open doors and windows allow quicker air exchange of air from indoor air reducing their concentration in indoor air. Low PM $_{2.5}$ concentration in kitchens with open windows and doors also implies that no significant amount of $\mathrm{PM}_{2.5}$ infiltrated indoor air from outdoor. 
Also, $95 \%$ of the kitchen windows/doors did not allow cross ventilation and had higher $\mathrm{PM}_{2.5}$ concentration $\left(0.55 \mathrm{mg} / \mathrm{m}^{3}\right)$ than those that allowed cross ventilation $\left(0.14 \mathrm{mg} / \mathrm{m}^{3}\right)$. On average, there was a significant difference between $\mathrm{PM}_{2.5}$ in kitchens with closed windows/ doors and those with open windows/doors $(p=0.016)$. Kitchens should therefore be constructed with doors/windows facing one another to allow cross ventilation which also allows quicker exchange of indoor pollutants.

\subsection{Heavy metal concentrations in $\mathrm{PM}_{2.5}$}

$\mathrm{PM}_{2.5}$ from each kitchen was analyzed for metals $\mathrm{Zn}, \mathrm{Cu}$, $\mathrm{Pb}, \mathrm{Fe}, \mathrm{Cd}$ and $\mathrm{Cr}$ using an ICP-OES. The calibration curves for all the six metals demonstrated good linearity over the concentration range $(0.1-20.0 \mathrm{mg} / \mathrm{L})$ with correlation coefficients $\left(R^{2}\right)$ in the range of $0.996-0.999$. The limits of detection (LODs) were determined using the calibration data and were $0.000002 \mathrm{mg} / \mathrm{L}$ for $\mathrm{Cu}, 0.000002 \mathrm{mg} / \mathrm{L} \mathrm{Cd}$, $0.000006 \mathrm{mg} / \mathrm{L} \mathrm{Pb}, 0.000002 \mathrm{mg} / \mathrm{L} \mathrm{Zn}, 0.000003 \mathrm{mg} / \mathrm{L} \mathrm{Fe}$ and $0.000005 \mathrm{mg} / \mathrm{L} \mathrm{Cr}$.

Concentrations of heavy metals in $\mathrm{PM}_{2.5}$ in different kitchens are reported in Table 4. Among the kitchens considered, a large number of kitchens (62.1\%) had iron present in its PM and $6.9 \%$ had cadmium present in its PM. Although all the elements can originate from biomass combustion as shown by previous studies [37], iron is also classified among mineral components, copper among traffic-related components, lead among tracer of heavy oil combustion, and cadmium, zinc and chromium among industrial elements [37]. Cadmium, zinc and chromium were present in kitchens located near areas with motor vehicle emissions which are sources of these metals. The outdoor air polluted with them could have entered into indoor air and this is supported by results of a related study investigating indoor air quality in commercial kitchen which indicate higher amount of indoor $\mathrm{PM}_{2.5}$ in food centers located towards the roadside pavement and this was attributed to infiltration of outdoor air into indoor [38].

Among the kitchens with mud floors, $88 \%$ had iron present in their $\mathrm{PM}_{2.5}$ indicating that floor dust could be one of the potential sources of iron metal. Previous studies have associated dust to heavy metal presence in particulate matter and results of a study measuring heavy metal concentrations in indoor dust in Malaysia indicate higher concentration of iron compared to other metals [39]. Therefore the observed large number of kitchens with mud floors could have generated a lot of dust leading to contamination of indoor air with iron. This is likely to be substantial where there is daily sweeping of kitchens that results into a lot of dust. In addition to sweeping, burning of plastics is another major source of heavy metals like $\mathrm{Cd}, \mathrm{Cr}, \mathrm{Pb}$, and since some of the households were burning plastics like polyethene bags when making charcoal fire, they are at a risk of heavy metal pollution. No metal was detected in four kitchens which had cemented floors while only one kitchen with mud floor in Kamukuzi Division had all the metals detected in its indoor $\mathrm{PM}_{2.5}$ indicating that floor type influenced the presence of metals in kitchen indoor air.

Generally, mean metal concentrations for all metals were lower than recommended exposure levels by EPA (Table 4) but these low concentrations if inhaled continuously can bio-accumulate to hazardous levels hence the need for their emission reductions. A similar study in China observed higher concentrations of lead $(0.09 \mu \mathrm{g} /$ $\left.\mathrm{m}^{3}\right)$ in indoor $\mathrm{PM}_{2.5}$ but lower zinc $\left(0.24 \mu \mathrm{g} / \mathrm{m}^{3}\right)$, copper $\left(0.02 \mu \mathrm{g} / \mathrm{m}^{3}\right)$ and chromium $\left(0.03 \mu \mathrm{g} / \mathrm{m}^{3}\right)$ concentrations [40] than those observed in this study. However, the $\mathrm{PM}_{2.5}$ analyzed came from different environments using gas fuel as opposed to charcoal fuel used in this study.

\subsection{Mean $24 \mathrm{~h}$ carbon monoxide concentration in kitchens}

Between February and April 2018 we monitored 56 households using the Pac 7000 that recorded and logged the peak concentration that occurred within each minute during the monitoring period following the method by Balakrishnan, K., et al. [31]. Each participating household was monitored for $24 \mathrm{~h}$ and the mean $24-\mathrm{h} \mathrm{CO}$ concentrations for each kitchen are reported in Table 5.

The concentration of $\mathrm{CO}$ varied within households in different divisions because of different kitchen characteristics and fuels although the differences were not statistically significant $(p=0.102)$ as shown in Table 5. Nyamitanga had the highest $\mathrm{CO}$ concentration (62.6 ppm) while Kakiika had the lowest (15.8 ppm). This can be attributed to the use of kerosene in some households in Nyamitanga, which is a significant contributor of $\mathrm{CO}$ to indoor air in addition to charcoal and wood compared to Kakiika where all households use only charcoal and wood.

It is important to note that the mean 24-h CO concentrations (41.5 ppm) were higher than the World Health Organization (WHO) 24-h Air Quality Guideline of $6.34 \mathrm{ppm}$. This is also similar to results from a related study in Sierra Leon [34] Furthermore, high CO levels (44 ppm) were observed in another study assessing indoor air in peri-urban areas of Kampala [41]. All the studies examined households using charcoal fuel and indicate a high risk of $\mathrm{CO}$ poisoning. Therefore, more efforts should be taken to control CO levels in kitchens. 
Table 4 Mean concentrations of metals in $\mathrm{PM}_{2.5}$ in different kitchens

\begin{tabular}{|c|c|c|c|c|c|c|c|}
\hline Household ID & $\begin{array}{l}\mathrm{Cu} \\
\mu \mathrm{g} / \mathrm{m}^{3}\end{array}$ & $\begin{array}{l}\mathrm{Cd} \\
\mu \mathrm{g} / \mathrm{m}^{3}\end{array}$ & $\begin{array}{l}\mathrm{Pb} \\
\mu \mathrm{g} / \mathrm{m}^{3}\end{array}$ & $\begin{array}{l}\mathrm{Zn} \\
\mu \mathrm{g} / \mathrm{m}^{3}\end{array}$ & $\begin{array}{l}\mathrm{Fe} \\
\mu \mathrm{g} / \mathrm{m}^{3}\end{array}$ & $\begin{array}{l}\mathrm{Cr} \\
\mu \mathrm{g} / \mathrm{m}^{3}\end{array}$ & Division \\
\hline 001-BIHA & $0.148 \pm 0.001$ & ND & ND & $7.068 \pm 0.034$ & ND & ND & Biharwe \\
\hline 002-BIHA & ND & ND & ND & ND & $4.976 \pm 0.011$ & ND & Biharwe \\
\hline 003-BIHA & $0.092 \pm 0.001$ & ND & $0.004 \pm 0.000$ & $0.06 \pm 0.050$ & $5.416 \pm 0.002$ & $0.04 \pm 0.002$ & Biharwe \\
\hline 004-BIHA & $0.076 \pm 0.001$ & ND & ND & ND & $6.268 \pm 0.011$ & $0.056 \pm 0.013$ & Biharwe \\
\hline 005-BIHA & $0.048 \pm 0.001$ & ND & ND & $1.144 \pm 0.005$ & $5.172 \pm 0.007$ & $0.028 \pm 0.009$ & Biharwe \\
\hline 006-BIHA & ND & ND & ND & $1.4 \pm 0.208$ & $1.268 \pm 0.080$ & $0.02 \pm 0.002$ & Biharwe \\
\hline 007-BIHA & ND & ND & $0.016 \pm 0.002$ & $0.72 \pm 0.015$ & $9.256 \pm 0.051$ & $0.052 \pm 0.021$ & Biharwe \\
\hline 008-BIHA & ND & ND & ND & ND & $2.364 \pm 0.012$ & $0.044 \pm 0.004$ & Biharwe \\
\hline 009-BIHA & ND & ND & ND & ND & $1.012 \pm 0.005$ & $0.068 \pm 0.003$ & Biharwe \\
\hline 010-BIHA & ND & ND & ND & $5.556 \pm 0.116$ & $5.336 \pm 0.016$ & $0.072 \pm 0.016$ & Biharwe \\
\hline 001-KAKI & $0.152 \pm 0.005$ & ND & ND & ND & $1.272 \pm 0.002$ & ND & Kakiika \\
\hline 002-KAKI & $0.052 \pm 0.002$ & $0.004 \pm 0.000$ & ND & $9.952 \pm 0.055$ & ND & ND & Kakiika \\
\hline 003-KAKI & ND & ND & ND & ND & ND & ND & Kakiika \\
\hline 004-KAKI & ND & ND & ND & ND & $5.016 \pm 0.003$ & ND & Kakiika \\
\hline 005-KAKI & ND & ND & ND & ND & $2.152 \pm 0.009$ & ND & Kakiika \\
\hline 006-KAKI & ND & ND & ND & ND & ND & $0.092 \pm 0.045$ & Kakiika \\
\hline 007-KAKI & ND & ND & $0.052 \pm 0.001$ & ND & $5.092 \pm 0.010$ & ND & Kakiika \\
\hline 008-KAKI & $0.128 \pm 0.001$ & ND & ND & $4.028 \pm 0.291$ & $3.764 \pm 0.005$ & ND & Kakiika \\
\hline 009-KAKI & ND & ND & ND & ND & ND & ND & Kakiika \\
\hline 010-KAKI & ND & ND & ND & ND & $6.74 \pm 0.003$ & $0.052 \pm 0.026$ & Kakiika \\
\hline 001-КАКО & ND & ND & ND & ND & ND & ND & Kakoba \\
\hline 002-KAKO & ND & ND & ND & $9.152 \pm 0.011$ & $4.616 \pm 0.005$ & ND & Kakoba \\
\hline 003-КАКО & ND & ND & ND & ND & ND & $0.068 \pm 0.030$ & Kakoba \\
\hline 004-КАКО & ND & ND & ND & ND & $5.38 \pm 0.006$ & ND & Kakoba \\
\hline 005-KAKO & ND & ND & ND & $1.944 \pm 0.130$ & ND & $0.064 \pm 0.004$ & Kakoba \\
\hline 006-KAKO & ND & ND & ND & ND & $5.016 \pm 0.006$ & $0.06 \pm 0.036$ & Kakoba \\
\hline 007-KAKO & ND & ND & ND & ND & $5.06 \pm 0.045$ & ND & Kakoba \\
\hline 008-КАКО & $0.124 \pm 0.003$ & ND & ND & ND & $9.82 \pm 0.025$ & ND & Kakoba \\
\hline 009-КАКО & ND & ND & ND & $7.08 \pm 0.119$ & $6.336 \pm 0.003$ & ND & Kakoba \\
\hline 010-КАКО & $0.068 \pm 0.002$ & ND & ND & ND & $5.056 \pm 0.042$ & ND & Kakoba \\
\hline 001-KAM & $0.136 \pm 0.004$ & ND & $0.048 \pm 0.002$ & $10.748 \pm 0.309$ & $5.016 \pm 0.005$ & $0.076 \pm 0.006$ & Kamukuzi \\
\hline 002-KAM & $0.1 \pm 0.058$ & ND & ND & $5.548 \pm 0.005$ & ND & ND & Kamukuzi \\
\hline 003-KAM & ND & ND & ND & $4 \pm 0.208$ & ND & ND & Kamukuzi \\
\hline 004-KAM & ND & ND & ND & ND & $8.76 \pm 0.046$ & ND & Kamukuzi \\
\hline 005-KAM & $0.12 \pm 0.014$ & $0.004 \pm 0.000$ & ND & $3 \pm 0.100$ & $1.5 \pm 0.010$ & ND & Kamukuzi \\
\hline 006-KAM & ND & ND & ND & $8.096 \pm 0.005$ & $1.496 \pm 0.005$ & $0.06 \pm 0.015$ & Kamukuzi \\
\hline 007-KAM & ND & ND & ND & $9.596 \pm 0.242$ & ND & ND & Kamukuzi \\
\hline 008-KAM & ND & ND & ND & ND & ND & $0.036 \pm 0.004$ & Kamukuzi \\
\hline 009-KAM & $0.108 \pm 0.002$ & ND & ND & ND & ND & $0.032 \pm 0.003$ & Kamukuzi \\
\hline 010-KAM & ND & $0.004 \pm 0.000$ & ND & ND & $5.456 \pm 0.006$ & $0.08 \pm 0.006$ & Kamukuzi \\
\hline 001-NYAK & ND & ND & $0.004 \pm 0.001$ & $1.54 \pm 0.092$ & $2.112 \pm 0.002$ & $0.052 \pm 0.042$ & Nyakayojo \\
\hline 002-NYAK & ND & ND & ND & $0.8 \pm 0.010$ & $7.92 \pm 0.032$ & ND & Nyakayojo \\
\hline 003-NYAK & $0.08 \pm 0.006$ & ND & ND & $10.296 \pm 0.005$ & ND & $0.076 \pm 0.006$ & Nyakayojo \\
\hline 004-NYAK & ND & ND & ND & ND & $8.532 \pm 0.022$ & $0.084 \pm 0.003$ & Nyakayojo \\
\hline 005-NYAK & $0.188 \pm 0.002$ & ND & ND & ND & $3.532 \pm 0.020$ & $0.068 \pm 0.010$ & Nyakayojo \\
\hline 006-NYAK & ND & ND & ND & $10.376 \pm 0.058$ & ND & ND & Nyakayojo \\
\hline 007-NYAK & ND & ND & ND & ND & $1.176 \pm 0.006$ & $0.056 \pm 0.010$ & Nyakayojo \\
\hline 008-NYAK & ND & ND & ND & ND & $8.616 \pm 0.055$ & ND & Nyakayojo \\
\hline 001-NYAM & ND & ND & $0.004 \pm 0.000$ & ND & $8.86 \pm 0.041$ & $0.044 \pm 0.001$ & Nyamitanga \\
\hline
\end{tabular}


Table 4 (continued)

\begin{tabular}{|c|c|c|c|c|c|c|c|}
\hline Household ID & $\begin{array}{l}\mathrm{Cu} \\
\mu \mathrm{g} / \mathrm{m}^{3}\end{array}$ & $\begin{array}{l}\mathrm{Cd} \\
\mu \mathrm{g} / \mathrm{m}^{3}\end{array}$ & $\begin{array}{l}\mathrm{Pb} \\
\mu \mathrm{g} / \mathrm{m}^{3}\end{array}$ & $\begin{array}{l}\mathrm{Zn} \\
\mu \mathrm{g} / \mathrm{m}^{3}\end{array}$ & $\begin{array}{l}\mathrm{Fe} \\
\mu \mathrm{g} / \mathrm{m}^{3}\end{array}$ & $\begin{array}{l}\mathrm{Cr} \\
\mu \mathrm{g} / \mathrm{m}^{3}\end{array}$ & Division \\
\hline 002-NYAM & ND & $0.004 \pm 0.002$ & $0.04 \pm 0.001$ & $6.748 \pm 0.100$ & $4.936 \pm 0.001$ & $0.012 \pm 0.003$ & Nyamitanga \\
\hline 003-NYAM & ND & ND & ND & $4.348 \pm 0.098$ & ND & ND & Nyamitanga \\
\hline 004-NYAM & $0.072 \pm 0.001$ & ND & ND & $7.096 \pm 0.005$ & ND & $0.048 \pm 0.039$ & Nyamitanga \\
\hline 005-NYAM & $0.132 \pm 0.001$ & ND & ND & $0.348 \pm 0.007$ & ND & $0.024 \pm 0.003$ & Nyamitanga \\
\hline 006-NYAM & $0.3 \pm 0.004$ & ND & $0.024 \pm 0.004$ & $9.696 \pm 0.006$ & ND & $0.036 \pm 0.000$ & Nyamitanga \\
\hline 007-NYAM & ND & ND & ND & ND & ND & ND & Nyamitanga \\
\hline 008-NYAM & ND & ND & ND & $9.556 \pm 0.015$ & ND & $0.048 \pm 0.024$ & Nyamitanga \\
\hline 009-NYAM & ND & ND & ND & $4.016 \pm 0.004$ & ND & ND & Nyamitanga \\
\hline 010-NYAM & $0.064 \pm 0.001$ & ND & $0.004 \pm 0.003$ & ND & $5.016 \pm 0.007$ & $0.028 \pm 0.017$ & Nyamitanga \\
\hline $\begin{array}{l}\text { Mean metal } \\
\text { concentrations } \\
\text { in households }\end{array}$ & $0.1152 \pm 0.059$ & $0.004 \pm 0.000$ & $0.021 \pm 0.020$ & $5.497 \pm 3.618$ & $4.981 \pm 2.517$ & $0.053 \pm 0.020$ & \\
\hline $\begin{array}{l}\text { EPA Recom- } \\
\text { mended } \\
\text { maximum level }\end{array}$ & 1.00 & 0.005 & 50.00 & 10.00 & 50.00 & 0.50 & \\
\hline
\end{tabular}

ND not detected

\subsection{Influence of household demographics on CO concentrations}

Households where family heads attained diploma had higher mean $\mathrm{CO}$ concentration $(65.7 \mathrm{ppm})$ followed by primary education (42.41 $\mathrm{ppm}$ ) then secondary $(40.87 \mathrm{ppm})$ and lastly degree $(23.8 \mathrm{ppm})$. All the households with diploma cooked from the main houses and used charcoal fuel which generates more CO compared to wood. Taylor and Nakai [34] in their investigation of levels of toxic air pollutants in kitchens using traditional stoves in rural Sierra Leone, also demonstrated that wood produces more PM while charcoal generates more CO.

The mean CO concentration was higher in households with six occupants ( $86.68 \mathrm{ppm}$ ) followed by those with four $(43.54 \mathrm{ppm})$, then households with three $(40.05 \mathrm{ppm})$ followed by those with seven (38.00 ppm), two (33.15 ppm), five (4.22 ppm) and lowest in households with one ocupant (1.99 ppm). On average, there was a significant difference in $\mathrm{CO}$ concentration across households with different number of occupants $(p=000)$. Lower CO concentrations observed in households with one participant was caused by fewer cooking times (one to two times) compared many coking times in households with many occupants.

\subsection{Effect of kitchen characteristics on CO concentrations}

Mean 24-h CO concentrations per kitchen and household characteristic are summarized in Table 1.

\subsubsection{Effect of cooking fuel on CO concentration}

Type of cooking fuel is an important factor that influences $\mathrm{CO}$ levels in kitchens. High CO levels were observed in kitchens using charcoal and kerosene (146.4 ppm) compared to those using charcoal and wood (55.4) or charcoal alone (25.2) and on average, there was a significant difference in $\mathrm{CO}$ concentration across all the cooking fuel types $(p=0.00)$ as expected.

\subsubsection{Influence of kitchen volume on CO concentration}

Increase in kitchen volume had no effect on CO concentration. This was shown by a low insignificant correlation observed when kitchen volume was compared with CO concentration, ( $p=0.074)$. This was not expected but it could have been influenced by other kitchen characteristics.

\subsubsection{Effect of roofing material on indoor $\mathrm{CO}$ concentrations}

Carbon monoxide concentration was $6.6 \mathrm{ppm}$ in 2 kitchens with concrete roof and $39.1 \mathrm{ppm}$ in those with metal roof which were 56 kitchens. Concrete roofs do not allow quick exchange of indoor air pollutants compared to metal roofs which have some vents. Kitchens with concrete roofs should therefore be constructed with enough ventilators to allow quick exchange of $\mathrm{CO}$ from indoor air. 
Table 5 Mean $24 \mathrm{~h}$ indoor CO concentrations in kitchens in Mbarara Municipality

\begin{tabular}{|c|c|c|c|c|c|c|c|c|c|}
\hline $\begin{array}{l}\text { Household } \\
\text { ID }\end{array}$ & $\begin{array}{l}\text { CO con- } \\
\text { centration } \\
(\mathrm{ppm})\end{array}$ & Range (ppm) & Division & $\begin{array}{l}\text { Mean CO } \\
\text { per division } \\
(\mathrm{ppm})\end{array}$ & $\begin{array}{l}\text { Household } \\
\text { ID }\end{array}$ & $\begin{array}{l}\text { CO con- } \\
\text { centration } \\
(\mathrm{ppm})\end{array}$ & Range (ppm) & Division & $\begin{array}{l}\text { Mean CO } \\
\text { per division } \\
\text { (ppm) }\end{array}$ \\
\hline 001-BIHA & 41.2 & $0-148$ & Biharwe & $43.1 \pm 36.4$ & 001-KAM & 52.11 & $0-211$ & Kamukuzi & $26.5 \pm 28.2$ \\
\hline 002-BIHA & 38.32 & $0-154$ & Biharwe & & 002-KAM & 4.2 & $0-79$ & Kamukuzi & \\
\hline 003-BIHA & 9.9 & $0-121$ & Biharwe & & 003-KAM & 78.98 & $0-331$ & Kamukuzi & \\
\hline 004-BIHA & 120.11 & $0-615$ & Biharwe & & 004-KAM & 55.23 & $0-426$ & Kamukuzi & \\
\hline 005-BIHA & 45.44 & $0-185$ & Biharwe & & 005-KAM & 2.46 & $0-22$ & Kamukuzi & \\
\hline 006-BIHA & 44.1 & $0-223$ & Biharwe & & 006-KAM & 43.45 & $0-441$ & Kamukuzi & \\
\hline 007-BIHA & 32.56 & $0-174$ & Biharwe & & 007-KAM & 4.44 & $0-104$ & Kamukuzi & \\
\hline 008-BIHA & 8.88 & $0-68$ & Biharwe & & 008-KAM & 7.98 & $0-65$ & Kamukuzi & \\
\hline 009-BIHA & 2.9 & $0-21$ & Biharwe & & 009-KAM & 2.98 & $0-34$ & Kamukuzi & \\
\hline 010-BIHA & 87.1 & $0-327$ & Biharwe & & 010-KAM & 13.56 & $0-154$ & Kamukuzi & \\
\hline 001-KAKI & 24.11 & $0-412$ & Kakiika & $15.8 \pm 15.1$ & 001-NYAK & 44.21 & $0-342$ & Nyakayojo & $52.4 \pm 46.4$ \\
\hline 002-KAKI & 3.02 & $0-36$ & Kakiika & & 002-NYAK & 141 & $0-639$ & Nyakayojo & \\
\hline 003-KAKI & 13.21 & $0-56$ & Kakiika & & 003-NYAK & 72.11 & $0-446$ & Nyakayojo & \\
\hline 004-KAKI & 42.11 & $0-196$ & Kakiika & & 004-NYAK & 24.38 & $0-182$ & Nyakayojo & \\
\hline 005-KAKI & 5.36 & $0-97$ & Kakiika & & 005-NYAK & 40.36 & $0-315$ & Nyakayojo & \\
\hline 006-KAKI & 41.65 & $0-312$ & Kakiika & & 006-NYAK & 3.32 & $0-43$ & Nyakayojo & \\
\hline 007-KAKI & 12.65 & $0-143$ & Kakiika & & 007-NYAK & 87.9 & $0-543$ & Nyakayojo & \\
\hline 008-KAKI & 4.57 & $0-22$ & Kakiika & & 008-NYAK & 6 & $0-99$ & Nyakayojo & \\
\hline 009-KAKI & 6.43 & 0-92 & Kakiika & & 001-NYAM & 9.97 & $0-76$ & Nyamitanga & $62.6 \pm 57.8$ \\
\hline 010-KAKI & 4.6 & $0-79$ & Kakiika & & 002-NYAM & 108.23 & $0-674$ & Nyamitanga & \\
\hline 001-КАKО & 161.01 & $0-723$ & Kakoba & $55.2 \pm 45.3$ & 003-NYAM & 40.01 & 0-196 & Nyamitanga & \\
\hline 002-КАKО & 30.12 & $0-412$ & Kakoba & & 004-NYAM & 41.81 & $0-706$ & Nyamitanga & \\
\hline 003-КАКО & 81.29 & $0-520$ & Kakoba & & 005-NYAM & 1 & $0-20$ & Nyamitanga & \\
\hline 004-КАКО & 80 & $0-432$ & Kakoba & & 006-NYAM & 23.12 & $0-233$ & Nyamitanga & \\
\hline 005-КАКО & 37.55 & $0-91$ & Kakoba & & 007-NYAM & 158.21 & $0-635$ & Nyamitanga & \\
\hline 006-КАКО & 44.12 & $0-669$ & Kakoba & & 008-NYAM & 118.1 & $0-1003$ & Nyamitanga & \\
\hline 007-KAKO & 5 & $0-43$ & Kakoba & & & & & & \\
\hline 008-КАКО & 60.12 & $0-448$ & Kakoba & & & & & & \\
\hline 009-КАКО & 7.45 & $0-104$ & Kakoba & & & & & & \\
\hline 010-KAKO & 44.91 & $0-519$ & Kakoba & & & & & & \\
\hline
\end{tabular}

\subsubsection{Effect of ventilation on Indoor CO Concentrations}

In Kitchens where cooking was done while windows and doors were open had lower CO concentration (37.4 ppm) than those that cooked with windows and doors closed (47.8 ppm) The difference in CO concentration across kitchens with closed and open windows was not significant $(p=0.363)$. This indicates that ventilation did not affect $\mathrm{CO}$ concentration significantly, $95 \%$ of the kitchen windows/doors did not allow cross ventilation and had higher $\mathrm{CO}$ concentration (43.3 ppm) than those that allowed cross ventilation (9.9 ppm) and this highlights the importance of cross ventilation in reducing $\mathrm{CO}$ concentrations by allowing quick circulation and exit of polluted air.

\subsubsection{Effect of cooking time on indoor $\mathrm{CO}$ concentration}

Increase in cooking time increases indoor CO concentration. This was evidenced by high $\mathrm{CO}$ concentration (46.56 ppm) in kitchens that cooked four times per day than in those that cooked fewer times. This increases the risk of exposure to $\mathrm{CO}$.

\section{Conclusion and recommendations}

This study determined the effect of charcoal fuel on concentrations of $\mathrm{PM}_{2.5}, \mathrm{CO}$ and heavy metals in kitchen indoor air in Mbarara Municipality Uganda. The results showed that charcoal fuel contributed to fine particulate 
matter ( $\mathrm{PM} \mathrm{2}_{2.5}$ ), heavy metals and carbon monoxide in kitchen indoor air thus it is a risk factor to human health. The study results also confirmed that kitchen characteristics like fuel, ventilation and volume affect the concentration and type of indoor air pollutants. There is a need for monitoring indoor air quality to ensure it meets standards.

While the observed results provide important information on indoor air quality in Mbarara town, there is need for further studies on personal exposure to air pollutants to clearly assess the health implications.

The study limitation was that $\mathrm{PM}_{2.5}$ and $\mathrm{CO}$ could not be measured throughout the year; instead measurements were made only in December 2017 for dry season and from February to April 2018 for wet season. Further research is needed to investigate long term variations on $\mathrm{PM}_{2.5}$ and $\mathrm{CO}$ concentrations by studying all the months throughout the year.

Acknowledgements The authors acknowledge Mbarara University of Science and Technology (MUST) and Mr. Godfrey Muhwezi of the Center for Integrated Research and Community Development Uganda (CIRCODU) for the research support.

Author contributions This work was done by NN under the supervision of Mr. DB and Associate Prof. GB during a Master of Science research.

Funding The study was self-funded.

Complaince with ethical standards

Conflict of interest There is no conflict of interest.

Consent for publication All authors consent to the publication of this work.

\section{References}

1. WHO (2007) Indoor air pollution: national burden of disease estimates. https://apps.who.int/iris/bitstream/handle/10665/69651 /WHO_SDE_PHE_07.01_eng.pdf?sequence=1\&isAllowed=y

2. Ozlem KK, Jingjing Z, Kent PE (2017) Pulmonary health effects of air pollution. Curr Opin Pulm Med 22(2):138-143 https://www. ncbi.nlm.nih.gov/pmc/articles/PMC4776742/

3. World Health Organization (2002) The health effects of indoor air pollution exposure in developing countries/by Nigel Bruce, Rogelio Perez-Padilla, and Rachel Albalak. World Health Organization, Geneva https://apps.who.int/iris/handle/10665/67496

4. Solomon BD (2004) Economic geography of energy. In: Cutler J (ed) Encyclopedia of energy. Elsevier Inc, Cleveland ISBN 978-0-12-176480-7

5. IEA (2016) World Energy Outlook 2016. IEA, Paris https://www. iea.org/reports/world-energy-outlook-2016

6. Bamwesigye D, Darkwah SA, Hlaváčková P, Vaclav K (2017) Firewood and charcoal production in Uganda. https://doi. org/10.5593/Sgem2017h/33/S14.065

7. Radulescu C, lordache S, Dunea D, Stihi C, Dulama ID (2014) Risk assessment of heavy-metals on public health associated with atmospheric exposure to $\mathrm{PM}_{2.5}$ in urban area. Rom J Phys 60(7-8):1171-1182

8. Mugo F, Wamono F, Ndemere AJ, Nturanabo F, van Tilborg C (2015) National charcoal survey for Uganda, Ministry Of Energy And Mineral Development (MEMD). https://unree ea.org/wp-content/uploads/2018/10/National-CharcoalSurvey_uganda.pdf

9. Yassin MF, AlThaqeb BEY, Al-Mutiri EAE (2012) Assessment of indoor PM 2.5 in different residential environments. Atmos Environ 56:65-68

10. Francis G, Ofosu FG, Hopke PK, Aboh IJK, Bamford SA (2013) Biomass burning contribution to ambient air particulate levels at Navrongo in the Savannah zone of Ghana. J Air Waste Manag Assoc 63(9):1036-1045

11. WHO (2004) Indoor air pollution, health and the burden of disease: indoor air thematic briefing 2. https://www.who.int/ ceh/capacity/Indoor_Air_Pollution.pdf

12. Riediker M, Cascio WE, Griggs TR, Herbst MC, Bromberg PA, Neas L, Williams RW, Devlin RB (2004) Particulate matter exposure in cars is associated with cardiovascular effects in healthy young men. AJRCCM 169(8)

13. Centres for Disease Control and Prevention (2016) Carbon monoxide poisoning. https://ephtracking.cdc.gov/showC oRisk.action

14. WHO (2013) Health effects of particulate matter. ISBN 978 928900001 7. http://www.euro.who.int/ data/assets/pdf file/0006/189051/Health-effects-of-particulate-matter-final -Eng.pdf

15. WHO (2005) Air guidelines for particulate matter, ozone, nitrogen dioxide and sulphur dioxide: global update 2005: summary of risk assessment. https://apps.who.int/iris/handl e/10665/69477

16. Mohanraj R, Azeez PA, Priscilla T (2004) Heavy metals in airborne particulate matter of urban Coimbatore. Environ Contam Toxicol 47(2):162-167

17. Straif K, Cohen A, Sametiarc J (2013) Air pollution and cancer. International Agency for Research on Cancer. https://www. iarc.fr/wp-content/uploads/2018/07/AirPollutionandCance r161.pdf

18. Nasir ZA, Ali Z, Ahmed S, Colbeck I (2013) Indoor particulate matter in developing countries: a case study in Pakistan and potential intervention strategies. Environ Res Lett 8(2013):024002 (8pp). https://doi.org/10.1088/1748-9326/8/2/

19. Lee SC, Chang M (2000) Indoor and outdoor air quality investigation at schools in Hong Kong. Chemosphere 41:109-113

20. Ooko S (2018) Africa and Asia worst hit by air pollution. Daily Nation. https://www.nation.co.ke/news/world/Nine-out-of10-people-breathing-polluted-air-WHO/1068-4540132-15kv0 I/index.html. Accessed 2 May 2018

21. Erica G (2016) Europe trails U.S. in cutting air pollution. The New York Times. https://www.nytimes.com/2016/05/12/scien ce/who-says-europe-trails-us-in-reducing-air-pollution.html. Accessed 1 Aug 2016

22. Baghani AN, Rostami R, Arfaeinia H, Hazrati S, Fazlzadeh $M$, Delikhoonf M (2018) BTEX in indoor air of beauty salons: risk assessment, levels and factors influencing their concentrations. Ecotoxicol Environ Saf 159:102-108

23. Abdel-Salam MMM (2015) Investigation of $\mathrm{PM}_{2.5}$ and carbon dioxide levels in urban homes. J Air Waste Manag Assoc 65(8):930-936 https://www.tandfonline.com/doi/ full/10.1080/10962247.2015.1040138

24. Susmita D, Paul M, Hussain SA (2015) Lessons from rural Madagascar on improving air quality in the kitchen. J Environ Dev 24(3):345-369. https://doi.org/10.1177/1070496515588590

25. IQAir (2018) World air quality report. https://www.airvisual.com/ world-most-polluted-countries 
26. Kirenga JB (2015) State of ambient air quality in two Ugandan cities. Int J Environ Res Public Health 12:8076. https://doi. org/10.3390/ijerph120708075

27. UBOS (2017) Mbarara district local government statistical abstract 2016/17. https://www.mbarara.go.ug/sites/default/ files/downloads/Statistical\%20Abstract\%202017\%20Final.pdf

28. WHO (2007) Indoor air pollution: National burden of disease estimates. https://apps.who.int/iris/bitstream/handle/10665 /69651/WHO_SDE_PHE_07.01_eng.pdf?sequence=1\&isAll owed $=y$

29. UBOS (2014) The population of the regions of the Republic of Uganda and all cities and towns of more than 15,000 inhabitants. Citypopulation.de Quoting Uganda Bureau of Statistics (UBOS). Accessed 21 Feb 2018

30. Smith S (2013) Determining sample size: how to ensure you get the correct sample size. E-Book (c) Qualtrics Online Sample

31. Balakrishnan K, Sambandam S, Ghosh S, Mukhopadhyay K, Vaswani M, Arora NK, Jack D, Pillariseti A, Bates MN, Smith RK (2015) Household air pollution exposures of pregnant women receiving advanced combustion cook stoves in India: implications for intervention, Ann Glob Health. 81(3):375-385. https:// doi.org/10.1016/j.aogh.2015.08.009

32. UBOS (2016) National population and housing census 2014. https://unstats.un.org/unsd/demographic/sources/census/ wphc/Uganda/UGA-2016-05-23.pd

33. Tang Z, Huang Q, Zhang L, Yang Y (2015) Contamination and risk of heavy metals in soils and sediments from a typical plastic waste recycling area in North China. Ecotoxicol Environ Saf 122:343-351

34. Taylor ET, Nakai S (2012) The levels of toxic air pollutants in kitchens with traditional stoves in rural Sierra Leone. J Environ Prot 3(10):1353-1363. https://doi.org/10.4236/jep.2012.310154
35. Muindi K, Kimani-Murage EW, Egondi T, Rocklöv J (2016) Household air pollution: sources and exposure levels to fine particulate matter in Nairobi slums. Toxics 4:12. https://doi. org/10.3390/toxics4030012

36. MEMDA (2001) National biomass energy demand strategy 2001-2010. http://www.energyandminerals.go.ug/downloads/ BEDS-Contents.pdf

37. Parajulia I, Lee H, Shrestha KR (2016) Indoor air quality and ventilation assessment of rural mountainous households of Nepal. Int J Sustain Built Environ 5(2):301-311

38. Bindu HES, Mahalakshmi RV (2013) Indoor air quality in commercial kitchens. Int J Sci Res (IJSR) ISSN (Online): 2319-7064

39. Sulaiman FR, Bakri NIF, Nazmi N, Latif MT (2017) Assessment of heavy metals in indoor dust of a university in a tropical environment. Environ Forens 18(1):74-82

40. Ghandi $K$ (2014) Chemical characteristics of indoor $\mathrm{PM}_{2.5}$ in urban China: an exposure assessment study. Public Health Theses. 1096. https://elischolar.library.yale.edu/ysphtdl/1096

41. BEIA (2012) Gambia, South Africa, and Uganda: technical assessment of Cookstove Projects. http://berkeleyair.com/gambi a-south-africa-uganda-technical-assessment-of-cookstoveprojects

Publisher's Note Springer Nature remains neutral with regard to jurisdictional claims in published maps and institutional affiliations. 